\title{
Compliance Costs of Regulation for Small Business
}

\author{
Phil Lewis, Alice Richardson and Michael Corliss \\ University of Canberra, Australia
}

\begin{abstract}
There has been growing concern about the extent of government regulation in Australia and its impact on small business. This paper examines the results of a survey of small businesses in NSW and Victoria regarding their experiences relating to compliance with government regulation, the costs to business, and factors inhibiting performance. The paper describes the development of the survey instrument, the administration of the survey, a description of the sample, results of the quantitative part of the survey, and an overview of business owners' comments provided by respondents.
\end{abstract}

\section{Introduction}

Small businesses are very important to the Australian economy. They account for over 47 percent of all employment, over 32 percent of wages and salaries, over 30 percent of sales and service income, over 42 percent of operating profit (before tax) and over 35 percent of industry value added (ABS 2012).

It is generally recognised that firms pursuing their own interests in competitive markets generally result in efficient allocation of resources, producing goods and services consumers want at the lowest prices. However, even the strong supporters of free markets acknowledge that some government intervention may be necessary to protect consumers, promote competition, correct for externalities, enforce contracts, protect private property rights, etc. (Lewis et al 2010). In addition, businesses are required to collect taxes and compulsory payments (such as superannuation contributions) on their own behalf and on behalf of employees plus taxes and charges on consumers (for example GST). Most of the regulations are legislated emphasising the benefits to society (for example, health and safety), but it is important that the benefits of such regulation are balanced by consideration of the costs. Just because something is beneficial doesn't mean government has to do it. A regulation is appropriate when the marginal benefit exceeds the marginal cost. It is difficult to believe, and borne out by work such as PC (2007), that the myriad of regulation facing small business can be justified under this criterion.

Costs of regulation can be conveniently divided into direct costs, allocative inefficiency and compliance costs. Direct costs consist of direct charges by government on businesses such as licences, fees, fine etc. These are easily measured and vary between businesses. For instance, a restaurant will generally need to pay for a liquor licence; a medical practitioner will need to be registered and so on.

Copyright (C) 2014 Victoria University. This document has been published as part of the Journal of Business Systems, Governance and Ethics in both online and print formats. Educational and non-profit institutions are granted a nonexclusive licence to utilise this document in whole or in part for personal or classroom use without fee, provided that correct attribution and citation are made and this copyright statement is reproduced. Any other usage is prohibited without the express permission of the publisher.
We do not consider these costs here.

Allocative inefficiency costs arise because in the presence of regulation businesses will behave differently than they would without regulation (otherwise regulation would not be necessary) with subsequent impacts on the type, quantity and prices of goods and services. For instance, licensing reduces competition which increases 
market prices and reduces quantity so that consumer welfare is reduced. Restaurants having to meet industrial relations laws may have the effect of reducing employment and reducing the hours or days in which consumers can get a meal. In the longer term regulation may well stifle innovation by restricting management prerogative on how to organise their business to reduce costs and provide better goods and services at lower prices. Although of considerable interest this aspect of regulation is beyond the scope of this study.

Compliance costs are the focus of this study. Compliance costs fall into three general categories. The first relates to becoming aware of regulations which must be abided by. The second relates to the costs of actually abiding by the regulation. For instance, health and safety regulation might prescribe the purchase of special equipment such as safety guards, helmets, wash basins, first aid kits etc. Compliance might involve hiring particular expertise (accountants, lawyers, for example), taking part in training or having to devote time by owners or staff in educating themselves in what exactly is required under legislation and the costs of non-compliance. The third category of costs relates to demonstrating compliance with legislation. This mostly involves record keeping, which increasingly involves computer packages but is often referred to as paperwork. The boundary between actually complying with legislation and demonstrating compliance can be somewhat blurred. The costs include hiring outside professional help devoting staff to compliance related activities or, quite likely for small businesses, the owner's own time.

\section{Background}

The burden of government regulation upon business has been an important issue for governments around the world since the 1990s. In Australia, as elsewhere these issues have centred on the growth in volume and the complexity of regulation (ACCI 2005). The Small Business Deregulation Taskforce (Bell 1996) identified a number of areas of government business regulation in which the recording and reporting requirements placed upon small business were judged to be excessive. Also it was reported there was a great deal of uncertainty about what was required in order to be compliant with government regulation and dealing with various jurisdictions added additional costs to businesses.

In recent years business groups in Australia have become very vocal about the increasing cost of compliance to business (PC 2007). The concern is less about the objectives of the regulation and more to do with perceived unnecessary additional costs associated with the policy design and implementation. There is legitimate concern over the expansion of regulation since the 1990s. For example, the number of pages of legislation passed through federal parliament since 1990 is more than had been passed during the first 90 years of federation (Banks 2006). While this doesn't automatically mean that the burden to business has increased by the same amount - some pieces of legislation were simply replacing old ones and other legislation was necessary for dealing with important social goals such as motor vehicle safety or pollution - still the cumulative effect has been to considerably increase regulatory burden for business (Banks 2006).

Here the focus is on the costs associated with regulation that is over and above the normal day to day running cost of a business, particularly if the regulation imposes costs upon those being regulated that are unnecessary. Such costs have been defined by the Productivity Commission (2009) as being a regulatory burden and include terms found in the literature, which are used interchangeably, such as compliance costs, administrative costs and regulatory costs (Chittenden et al 2002). Sandford et al (1989) define compliance costs as:

'for individuals, the cost of acquiring sufficient knowledge to meet their legal requirements; of compiling the necessary receipts and other data and of completing tax returns; payments to professional advisors for tax advice; and incidental costs of postage, telephone and travel in order to communicate with tax advisors or the tax office. For a business, the compliance costs include the cost of collecting, remitting and accounting for tax on the products or profits of the business and on the wages and salaries of its employees together with the costs of acquiring the knowledge to enable this work to be done including knowledge of their legal obligations and penalties' 
The costs of compliance to business are considered to be substantial, although quantifying these burdens has proved difficult (Banks 2006). Estimates on the conservative side put compliance costs to the Australian economy at tens of billions of dollars annually. The costs of regulation include time, paperwork, capital outlays, and deflection from core business activities. From the submissions sent to the Productivity Commission it is estimated that compliance can take up to 25 percent of the time of senior management and boards of large companies' time (Banks 2006).

A series of studies were undertaken in Australia with the aim of estimating the cost of compliance for the major taxes (Pope et al 1989, 1991, 1992; Pope et al 1990; Evans et al 1996, 1997). These studies focused on the overall cost of compliance costs associated with taxes in Australia. The major finding was that the estimated burdens were high with company income tax creating the greatest burden of all the taxes. Pope et al (1991) estimated that the gross taxation compliance costs were between 11.4 percent and 23.7 percent of revenue yield for the period 1986 to 1987. Evans et al (1997) however, suggests that the Pope studies had overestimated the compliance cost of taxation. They estimated these costs to be just 7 percent of revenue yield.

One area of the literature on the cost of compliance that is quite extensive is that of the cost of compliance for small business. In their review of the literature Chittenden et al (2002) found that in the countries they surveyed governments had accepted that there was a disproportionate cost burden placed upon small businesses. They suggest that the regulatory costs are some 35 percent higher for firms with less than 20 employees compared to firms with over 500 staff, although this figure should not be used as a rule of thumb due to comparison difficulties in the methodology. However, this figure should be seen as the minimum increase in compliance cost placed on small business. In fact it is commonly found that firms with less than 20 employees incur compliance costs that are several times greater than the costs incurred by large businesses (Inland Revenue 1998). In some instances while larger firms actually received a net benefit from regulation in the case of holding on to cash collected on behalf of government, smaller firms incurred a net loss (Sandford and Hasseldine 1992).

In Australia the Small Business Deregulation Taskforce was charged with reviewing the compliance burdens incurred by small business (Bell 1996). It defined small businesses as having fewer than 20 employees in the case of non-manufacturing firms and less than 100 employees in the case of manufacturing firms; and having a turnover of less than $\$ 10$ million. The Working Overtime Survey (Small Business Deregulation Task Force 1996), found small businesses were particularly concerned by: the complexity of taxation and employment regulations; administrative and compliance costs of dealing with regulations; lack of coordination between government agencies; poor scrutiny of regulation and review processes; and a lack of effective monitoring mechanisms. The major finding of the report was that, on average, small businesses spend 16 hours a week on administration and compliance costs. Of this, 8 hours are spent with accounts, bookkeeping and paying wages; government compliance and paperwork accounts for 4 hours, taxation matters consume 3 hours, and 1 hour is spent on other activities. In total 7 hours weekly are spent by small business in keeping compliant with government regulation. Additionally, the report suggested that on average small business spends $\$ 7000$ on total compliance costs, $\$ 3000$ of which is spent on external advice.

Banks (2006) also identifies small businesses as being disproportionately impacted by regulation suggesting that generally small business doesn't have the capacity to deal with and keep up to date with, as he puts it, the 'morass' of government regulation.

Research conducted by Evans et al (1997) and Walpole et al (1999) concluded that small businesses were particularly burdened by the compliance costs associated with taxation especially in terms of the number hours spent. Evans et al (1997) estimated that of all the time taken up with associated taxation compliance in the Australian economy, 90.7 percent of that time was borne by small business. In fact Evans et al (1997) found that large firms had a net benefit from taxation compliance due to tax deductions and cash flow benefits. An important finding is the regressive nature of taxation compliance costs. Evans et al (1997) estimated the average overall compliance costs associated with taxation in 1994/95 for firms with turnover less than $\$ 100,000$ was $\$ 24.71$ per $\$ 1,000$ of turnover, compared to $\$ 0.98$ for a medium size enterprise with turnover between $\$ 100,000$ - $\$ 9,999,999$ and 
$\$ 0.60$ for a large enterprise with turnover in excess of $\$ 10$ million. Other studies have also found taxation compliance costs to be regressive (see, for example, Pope et al 1991).

Various other factors have added to the cost of compliance in Australia. The disconnect and rivalry between levels of government in Australia has thwarted the development of a common legislative framework for SMEs in Australia (Buffini 2007). For example, licensed tradespersons acting in accordance with apprenticeship regulation in one state need to comply with different apprenticeship regulation in another state (Leung et al 2008). There is no single place to look up regulatory requirements. Small businesses must look over at least three political jurisdictions including federal, state and local government. Clarke (2010) reported on the complexity of child care regulation made worse by having both state and federal government involvement. They stated that some plans have been made to share or move power to one of competing authorities, usually the Commonwealth, to reduce the complexity.

The aim of this paper is to fill the gap in the Australian literature regarding a quantification of the costs of regulation in terms of both time and money. It also provides insight into how small businesses perceive the problems they face due to excessive regulation and their suggestions of how the burden of regulation can be eased.

Firstly this paper uses recent data to quantify the costs of compliance in both time and money across ten dimensions. Secondly, to examine the extent to which the costs differ according to firm size and source of advice. And finally, to extract themes for reducing compliance costs as reported by businesses themselves.

The rest of the paper is structured as follows. Exploratory data analysis to describe the sample is reported, followed by tests of the strength of the relationship between dimensions of compliance, cost of compliance and source of advice. The next section explores themes in the free text comments about compliance supplied by the businesses in DARRS 2010.

\section{Methodology}

The Developing a Responsive Regulatory System (DARRS) survey was conducted in 2010 in New South Wales and Victoria. After a series of interviews with business leaders, questions were developed to investigate the problems Australian businesses face with regards to government regulation and possible solutions. The researchers approached the members of the branches of the Council of Small Business of Australia (COSBOA) in those two states to administer the survey. The researchers asked the organisations to publish the URL of the survey in their newsletters. Responses to the survey were then collected directly from small businesses who were members of the organisations who published the link. Thus the sampling frame consists of all businesses who were members of organisations belonging to COSBOA in Victoria and New South Wales. There were 391 valid responses to various questions relating to business activity and the costs associated with being compliant with government regulation. The same survey has also been analysed from the point of view of determinants of regulatory burden by Li, Armstrong \& Clarke (2010).

\section{Sample Description}

Comparisons between the DARRS survey respondents and the profile of Australian businesses derived from the ABS Business Register (ABS 2007) are interesting. These comparisons show that DARRS has proportionately more older businesses with the greatest proportions found in the 10 to 20 years, 31.5 percent, and 20 years and over age category at 38.6 percent, a combined total of 71.5 percent. This compares to the ABS Business Register where the age categories with the greatest representation, 3 to 5 years and 10 to 20 years, have only 20.9 percent and 21.1 percent of the share of businesses, respectively. This indicates that respondents in the DARRS survey are generally more established businesses and this is to be expected given that they have been sampled through COSBOA. Businesses which have only had a short life to date are less likely to be part of business organisations such as COSBOA. 
The DARRS survey is dominated by three industries namely retail trade, 17.9 percent, professional services, 15.3 percent, and other services 23 percent of the sample. Businesses from any other industries made up less than 7 percent and some industries, such as mining and public administrations were missing from the sample entirely.

The bulk of businesses in the DARRS survey were in the 1 to 5 employee range accounting for 53 percent of the respondents and the 6 to 20 employees range accounting for 24 percent of respondents. The legal status of the firms in the sample were manly private companies 70 percent, with another 15 percent listed as a sole proprietor and 9 percent as a partnership. Most of the firms in the sample, 70 percent, had only 1 business site, 15 percent had between 2 to 4 business sites in Australian and 6 percent had 5 or more.

The definition of business size used here is that adopted by Heenetigala et al (2011). A business is defined as small if it has 20 or less employees, medium size if it has between 21 to 50 employees and large if the number of employees is greater than 50. Of those firms in the survey providing details of firm size, 9 percent had no employees, 53 percent had between 1 and 5 employees, 24 percent had between 6 and 20 employees, 8 percent had between 21 and 50 employees and 6 percent had over 50 employees.

\section{Results}

The results are reported in three sections:

First, the difficulty of compliance with ten types of regulation is discussed in terms of overall percentages. These percentages are then broken down by firm characteristics comprising firm size, legal status, age of firm and source of advice. These percentages are also broken down by numerical measures of firm performance comprising total sales, net profit and cost of compliance in dollars and cost of compliance in time.

Second, the cost of compliance is estimated across firms of different sizes.

Third, the free text responses of small businesses regarding the difficulty they have complying with regulation are discussed in terms of the ten types of regulation. Followed by the free text responses of small businesses regarding possible solutions to their difficulties are discussed. And a data-driven categorisation of responses is used, loosely based on the ten types of regulation mentioned earlier in the survey.

\section{Difficulty with Compliance}

Respondents were asked to rate the difficulty they have had with respect to a number of areas of regulation on a scale of 1 , not difficult at all, through to 5, most difficult. Here if a respondent rated a regulatory issue as either 4 or 5 this has been taken to mean the respondent has had difficulty maintaining compliance with this particular issue. In the figures below the number having difficulty are shown as a percentage of all respondents. 
Figure 1 Compliance Difficulty by Regulation Type, percent.

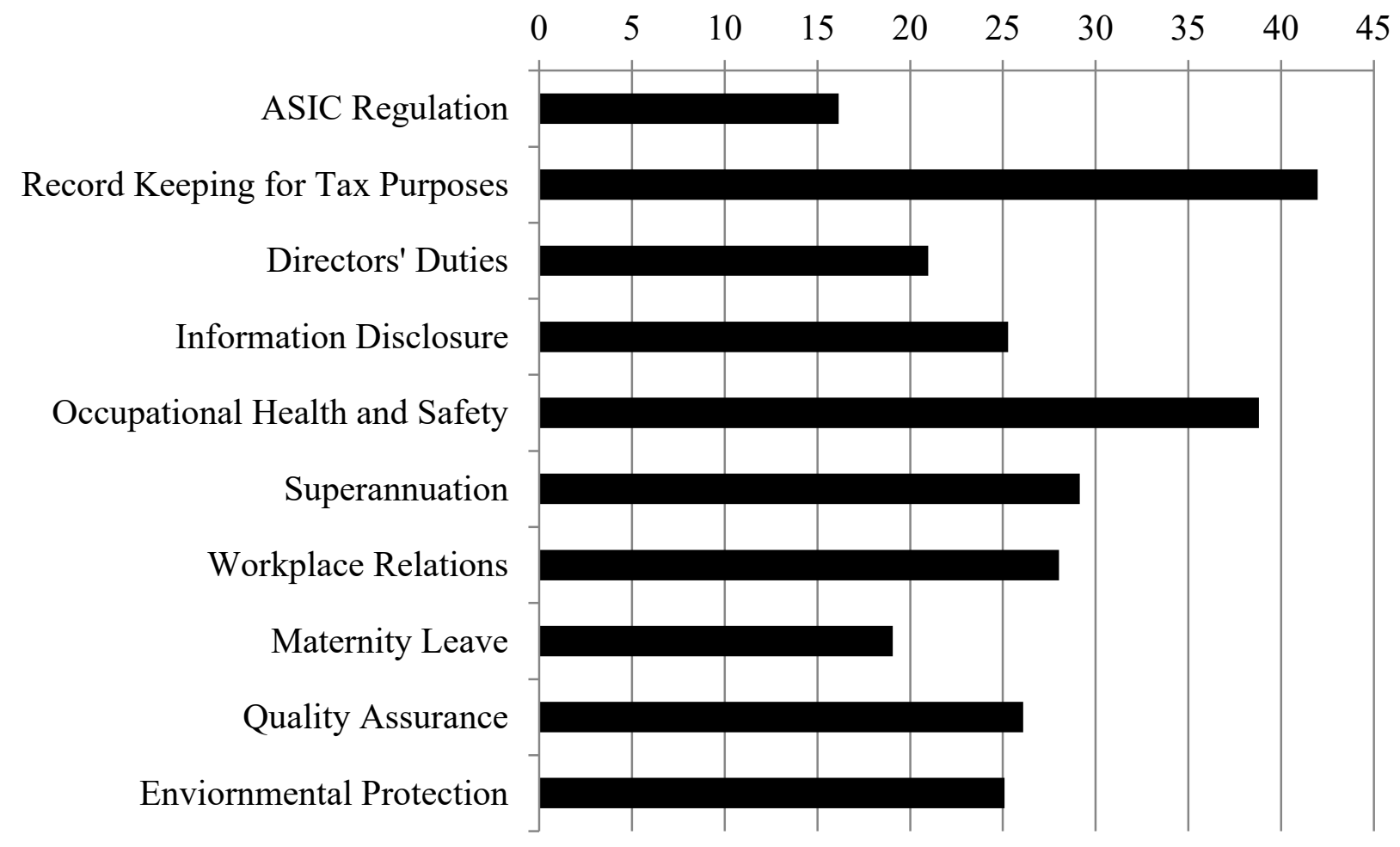

Source: DARRS 2010 Survey

Figure 1 shows the proportion of firms having difficulty with compliance by type of regulation. The greatest compliance difficulty appears to be associated with record keeping for tax purposes and occupation health and safety with 42 percent and 39 percent, respectively, of firms indicating they have difficulty with these types of regulation. Additionally, firms in the survey indicated that superannuation and workplace relationships are also quite difficult, although there were fewer respondents indicating difficulty with these types of regulation, 29 percent and 28 percent, respectively. ASIC regulation and maternity leave are associated with less difficulty in maintaining compliance, 16 percent and 19 percent, respectively. 
Figure 2 Compliance Difficulty by Firm Size, percent.

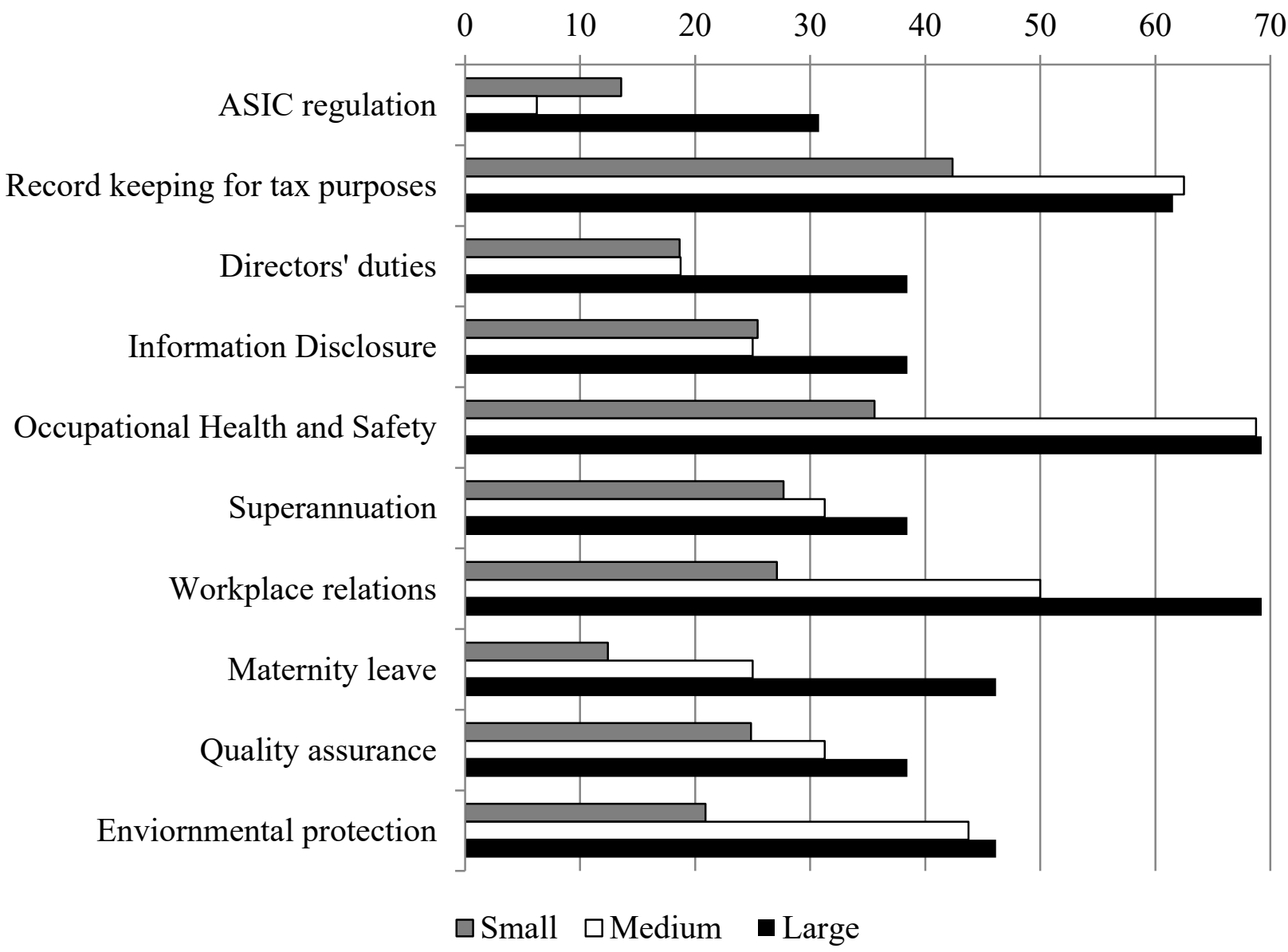

\section{Source: DARRS 2010 Survey}

It would be expected that the size of a firm influences the costs associated with maintaining compliance. For the smaller firm, while they may have less regulation to comply with, they also have fewer resources at their disposal. Conversely larger firms, while having more regulations to comply with, they also have greater resources available in order to do so. Figure 2 shows the proportion of firms by firm sizes that have difficulty keeping compliant with government regulation.

It appears that the three greatest problem areas of compliance are in record keeping for tax purposes, Occupational Health and Safety and workplace relationships for medium and large firms. For the larger firms, 69 percent of the firms surveyed had issues with workplace relationships and Occupational Health and Safety and 62 percent had issues with record keeping for tax purposes. Other regulatory areas such as maternity leave and environmental protection were also of concern to a number of large firms. Small firms, it seems, had less trouble dealing with these areas of regulation than did the large and medium size firms. The greatest issues for small firms were found in record keeping for tax purposes, with 42 percent of small firms having difficulty. Also, Occupational Health and Safety was an issue with 36 percent of small firms having difficulty complying 


\section{Figure 3 Compliance Difficulty by Legal Status, percent.}

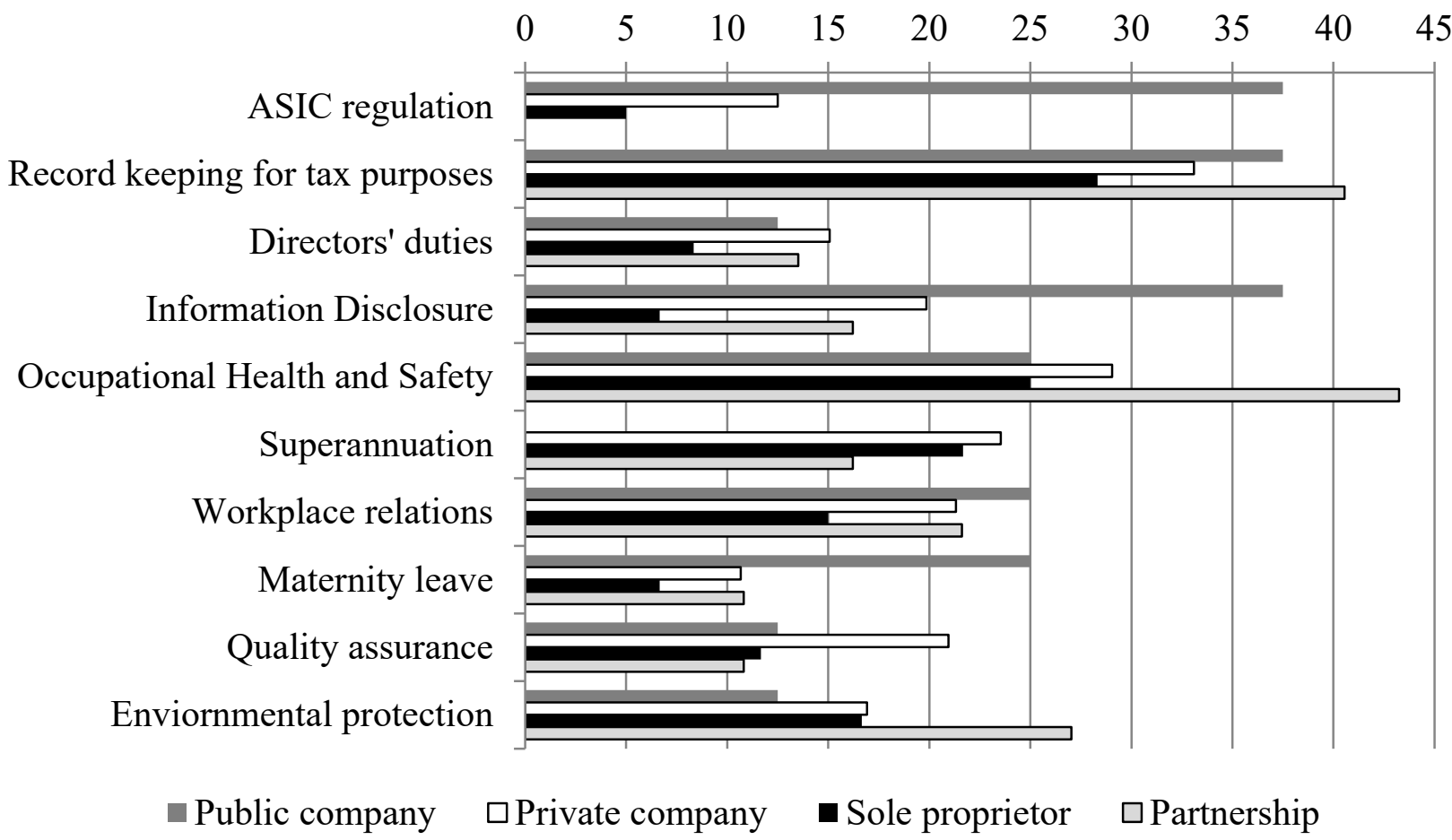

Source: DARRS 2010 Survey

Figure 3 shows the difficulty with compliance by firm legal status. It appears that partnership firms have the greatest difficulty in complying with record keeping for tax purposes, 41 percent, and Occupational Health and Safety, 43 percent. Public firms have the greatest difficulty complying with ASIC regulation, 38 percent, record keeping for tax purposes, 38 percent. and information disclosure, also 38 percent. While private and sole proprietor firms had the least difficulty dealing with record keeping for tax purposes and Occupational Health and Safety, they were still the greatest compliance issues for these types of firms.

Figure 4 shows the percentage of firms that have difficulty with compliance by age of firm. Newer firms are defined to be those less than 5 years old, established firms are 5 to 20 years old and the older firms are ones that have been in business for greater than 20 years. While the greatest difficulty keeping compliant appears to be associated with record keeping for tax purposes and occupational health and safety for the established and older firms, the newer firms tended to struggle with record keeping for tax purposes, information disclosure, superannuation, and quality assurance. The least difficulty with compliance can be associated with ASIC regulation and directors duties for established firms, occupational health and safety, maternity leave and environmental protection for newer firms and maternity leave for older firms. 
Figure 4 Compliance Difficulty by Age of Firm

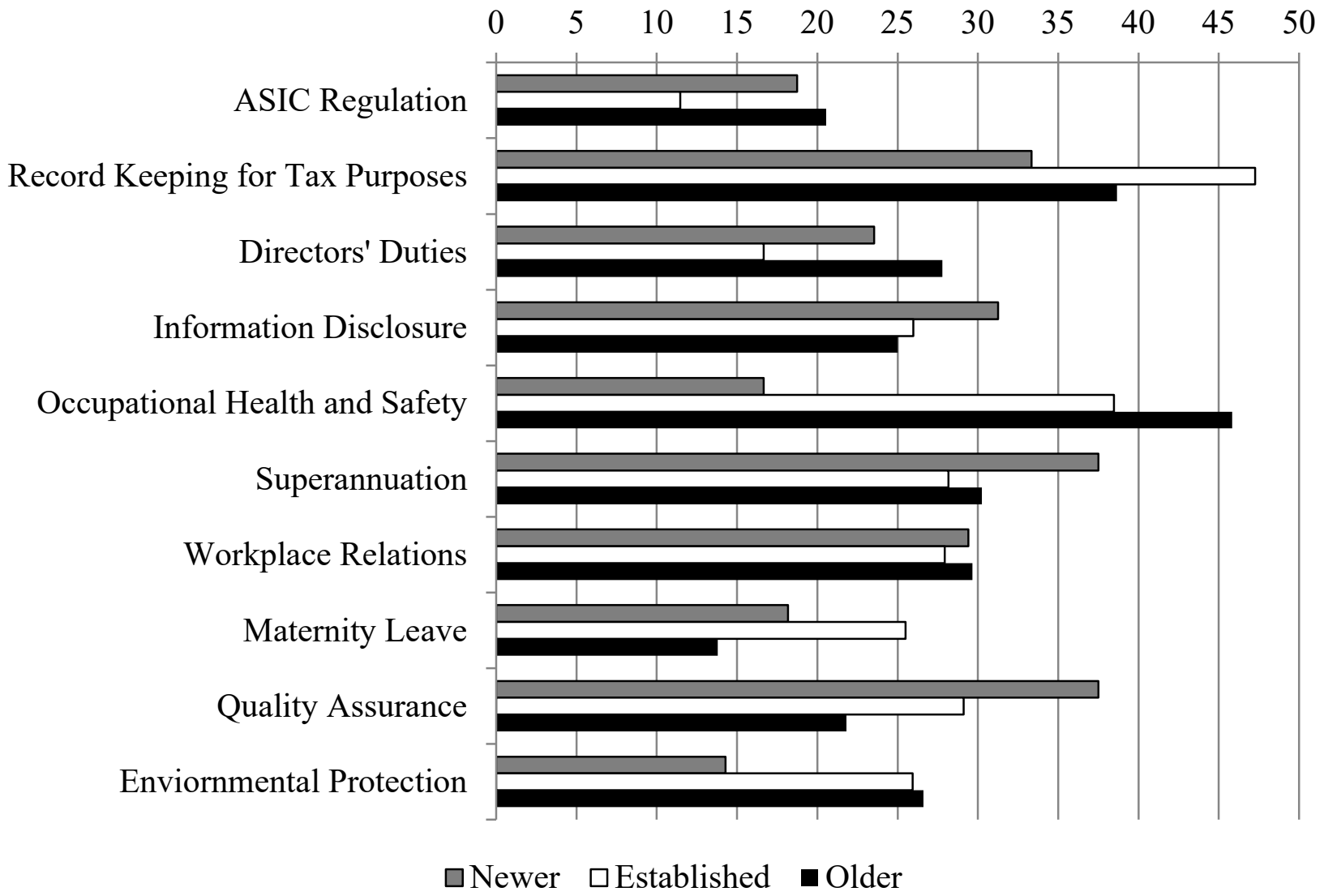

\section{Source: DARRS 2010 Survey}

The data in Figure 5 attempt to examine the extent to which the provision of advice by professionals improves business's ability to reduce difficulty with compliance. It shows the percentage difference in compliance difficulty between those firms that sought advice and those that didn't. Bars to the left indicate that businesses experienced decreased difficulty with a particular issue when advice was sought from a particular source. Bars to the right indicate that businesses experienced increased difficulty with a particular issue when advice was sought from a particular source. For example, while 16.2 percent of respondents that sought advice from an accountant found ASIC compliance difficult, 25 percent of respondents that didn't seek advice from accountant found ASIC regulation difficult, resulting in a -8.8 percent difference. This suggests that seeking the advice of accountants will likely reduce the difficulty firms have with being ASIC compliant. 


\section{Figure 5 Compliance Difficulty by Sources of Advice}

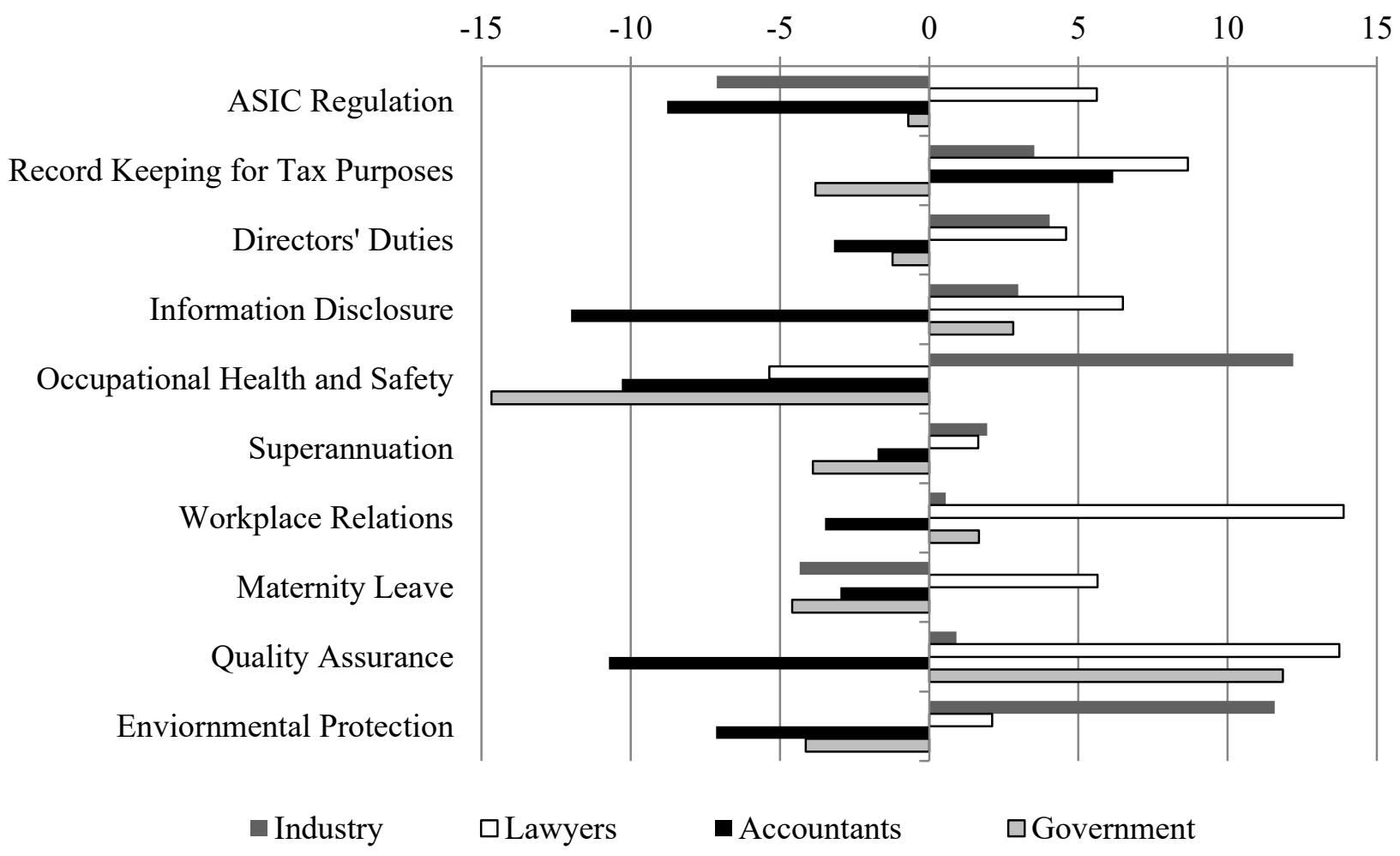

Source: DARRS 2010 Survey

The results suggest that generally accountants and government are the best form of advice and lawyers are associated with being the worst form of advice. Advice from accountants is associated with the greatest reduction in compliance difficulty in ASIC regulation, directors' duties, information disclosure, workplace relations, quality assurance and environmental protection. Government advice is also associated with the greatest reductions in compliance difficulty for record keeping for tax purposes, occupation health and safety, superannuation and maternity leave. Advice from lawyers, on the other hand, is often associated with greater compliance difficulty, particularly for ASIC regulation, record keeping for tax purposes, information disclosure, workplace relationships, maternity leave and quality assurance. This is likely a reflection not upon the advice given from lawyers but upon matters that have taken place in the workplace that require legal advice.

Figure 6 shows compliance difficulty by total sales. The figure suggests that sales volume is positively associated with compliance difficulty. In particularly this is evident in record keeping for tax purposes, occupational health and safety, workplace relationships, quality assurance and environmental protection. While the positive association is not as clear for maternity leave, businesses with total sales of 10 million and greater did have the greatest difficulty in complying with maternity leave. 
Figure 6 Compliance Difficulty by Total Sales

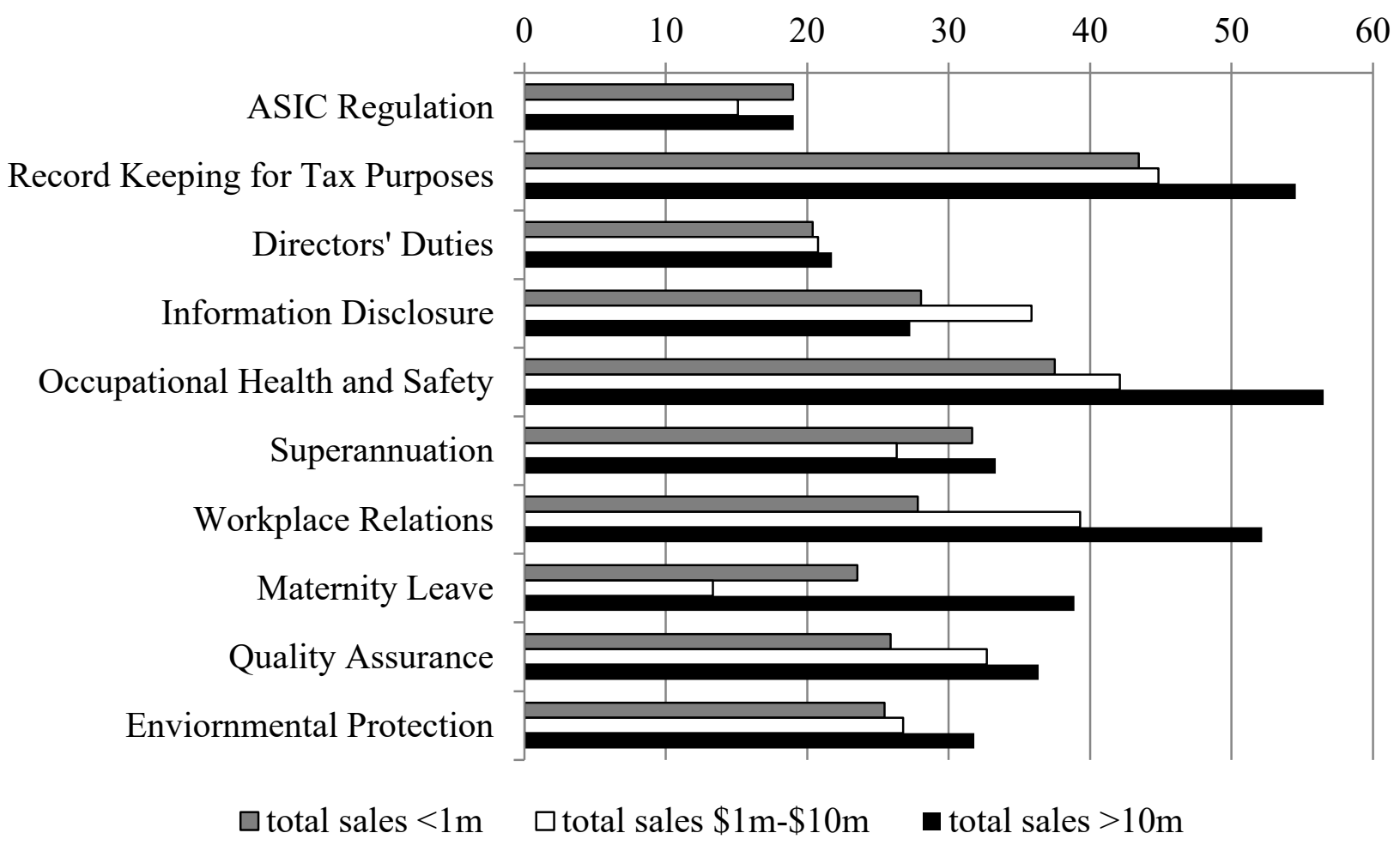

Source: DARRS 2010 Survey

Figure 7 shows compliance difficulty by net profit. Interestingly there is not the same positive association as that associated between total sales and compliance difficulty. Here it appears that the net profit category of $\$ 1-\$ 10$ million is associated with the greatest compliance difficulty. The net profit category of greater than $\$ 10$ million is actually associated with a significant reduction in compliance difficulty when compared to the profit category of $\$ 1-\$ 10$ million. In fact in some cases of regulation such as ASIC regulation, record keeping for tax purposes, directors' duties and information disclosure, the net profit category of greater than $\$ 10$ million had the least difficulty with compliance. This is perhaps evidence that a competency in dealing with government regulation is significantly associated with better performance, in this case net profit. 


\section{Figure 7 Compliance Difficulty by Net Profit}

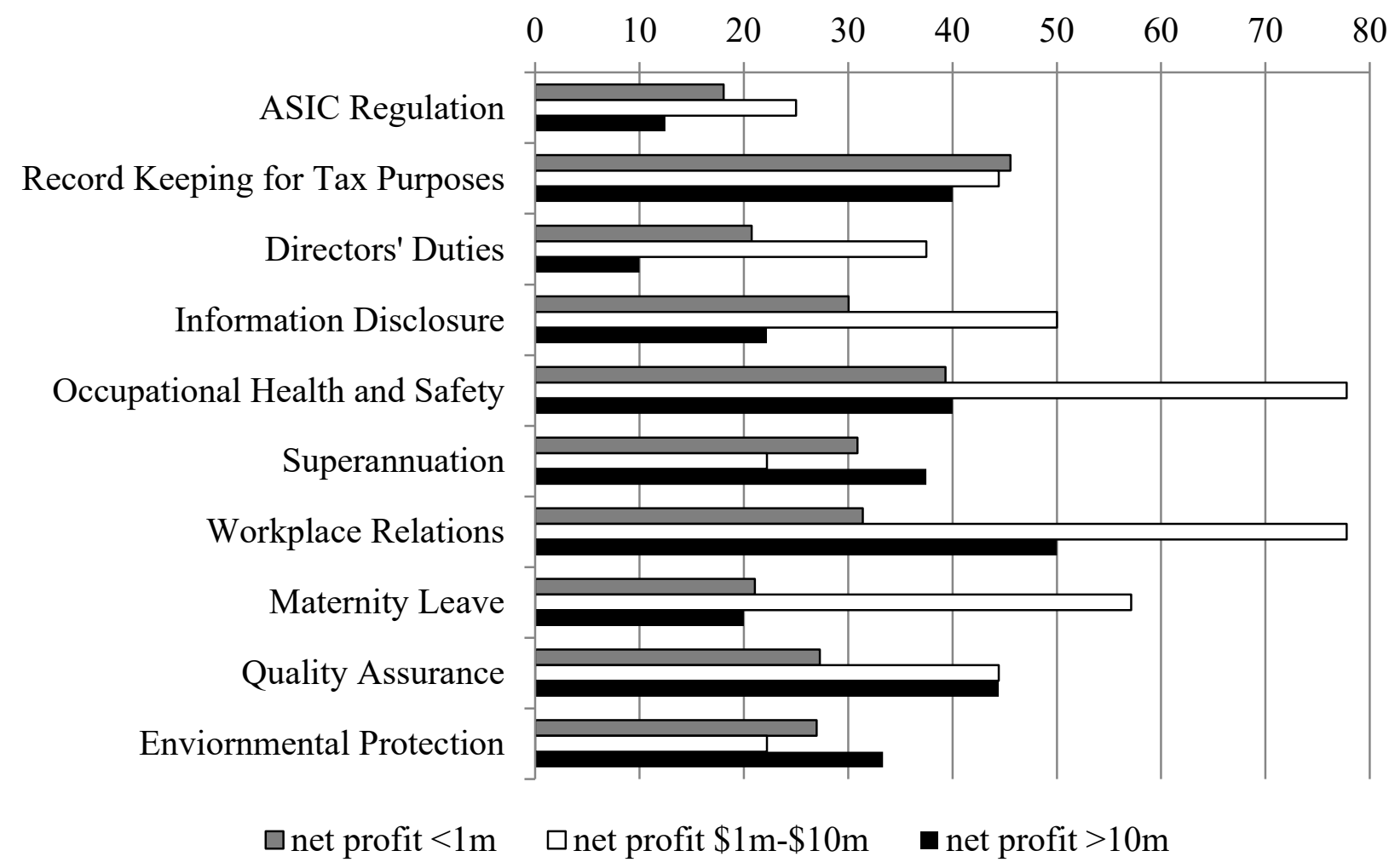

Source: DARRS 2010 Survey

It would be expected that if compliance is more difficult then there would be an increased cost of compliance. This largely borne out by Figure 8 which shows the relation between the difficulty with compliance and the dollar cost of compliance. Generally speaking there appears to be a discernible positive association between the difficulty with compliance and the dollar cost of being compliant. This is the case for a number of the regulation types such as ASIC regulation, record keeping for tax purposes, Occupational Health and Safety, superannuation and quality assurance. For other types of regulation the increase in compliance costs is not as clearly associated with the difficulty in compliance, for example directors' duties, information disclosure, workplace relationships and maternity leave. However, the highest category for cost of compliance was also associated with the greatest difficulty. This has important implications for any future reform of small business regulation since reducing the difficulty with compliance will also reduce the compliance costs to businesses. 


\section{Figure 8 Compliance Difficulty by Cost of Compliance (\$)}

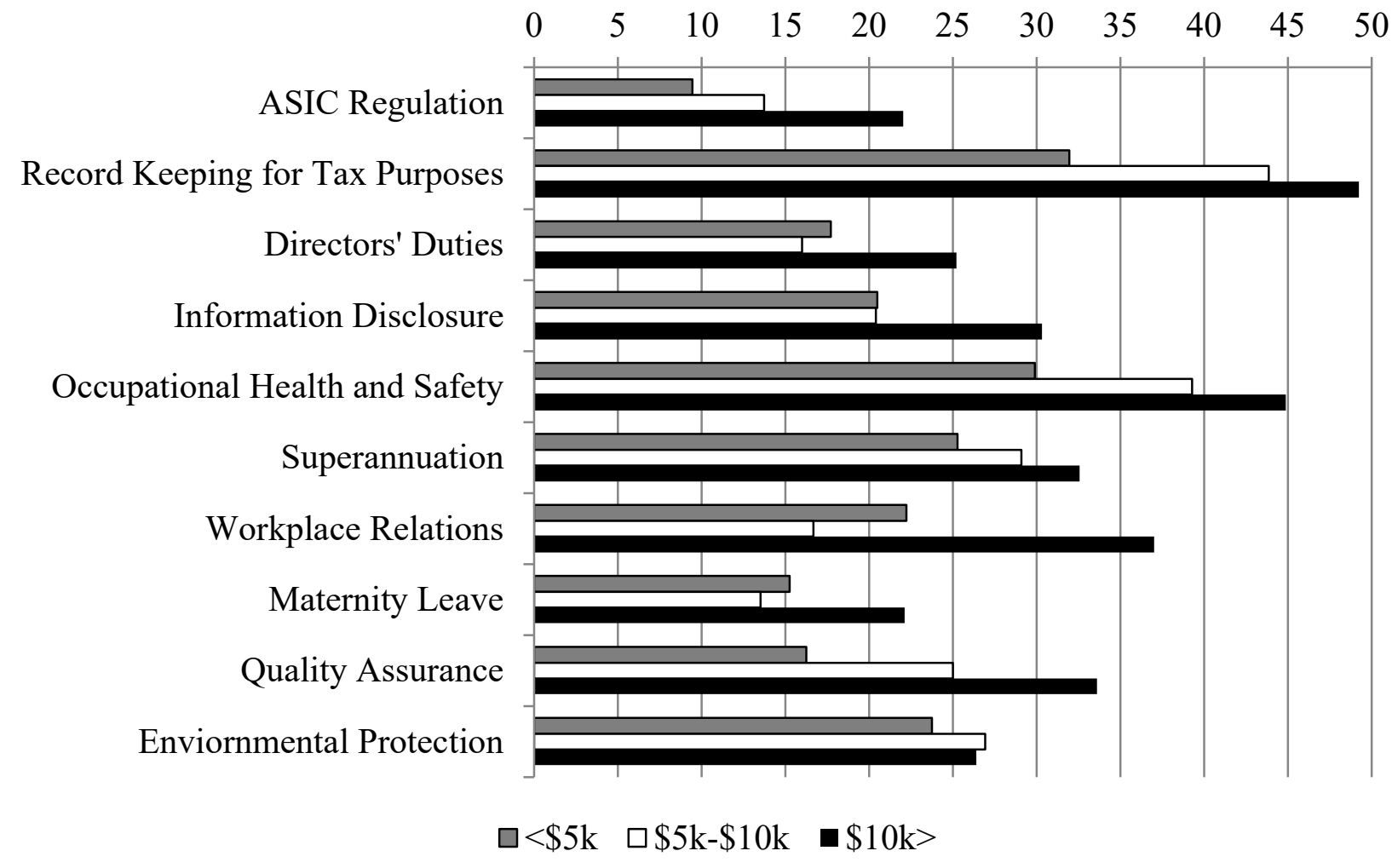

Source: DARRS 2010 Survey

Figure 9 shows the difficulty with compliance by the cost of compliance in days. As in figure 8, the same positive association between the difficulty with compliance and the cost of being compliant in days exists. This is the case for a number of the regulation types such as directors' duties, information disclosure, occupational health and safety, workplace relationships, quality assurance and environmental protection. 
Figure 9 Compliance Difficulty by Cost of Compliance (Days)

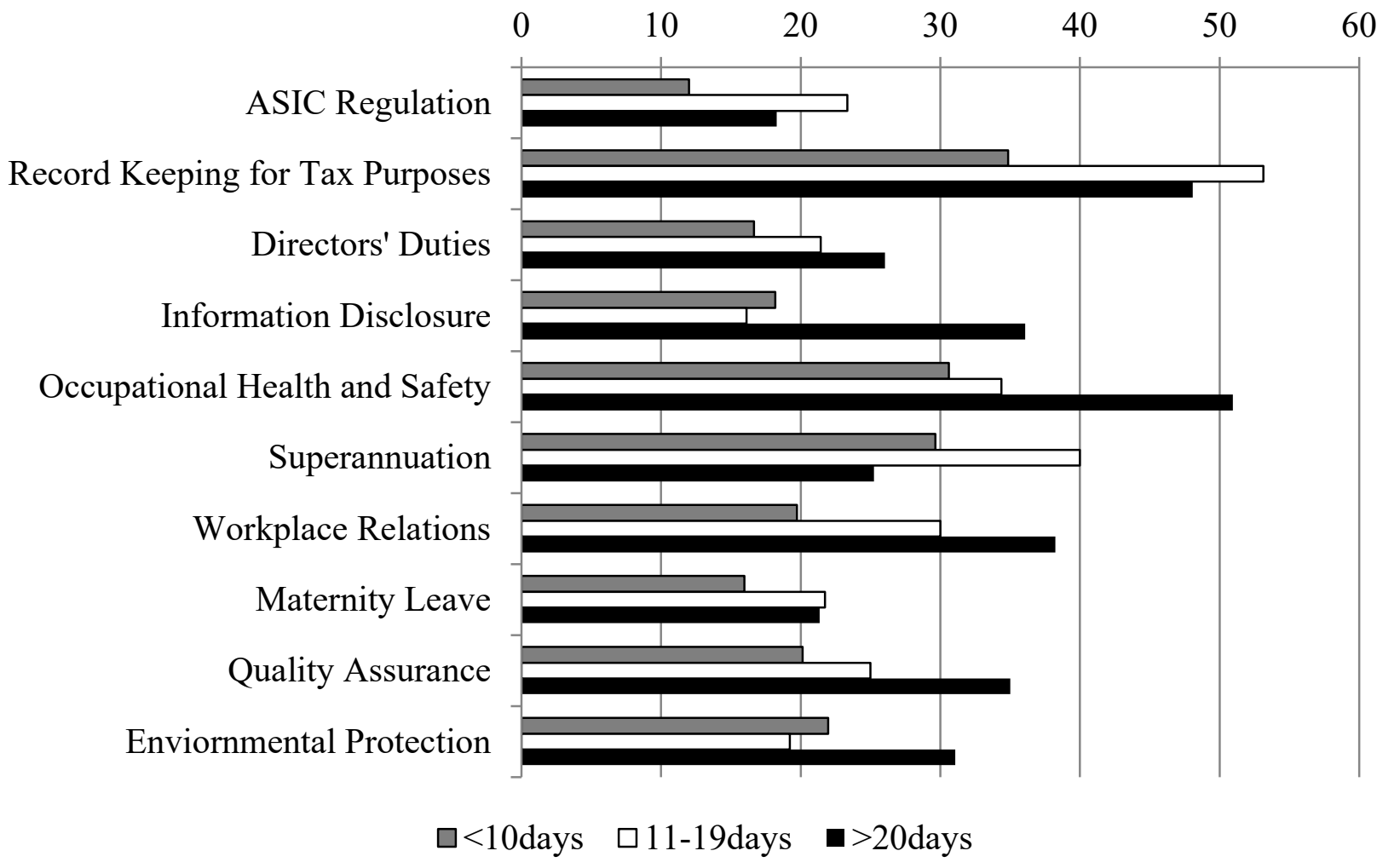

Source: DARRS 2010 Survey

\section{Cost of Compliance}

Table 1 below shows the median cost per business of compliance with government regulation by firm size as measured by number of employees. The estimates are calculated from the responses of small businesses to the survey. Businesses were asked to estimate both the number of days per year devoted to compliance and to estimate the costs of compliance. The time spent includes only both the owners' own time and that of employees. The monetary cost includes not just time within the firm but also fees paid outside the firm such as accountants.

Table 1: Median compliance cost by firm size.

\begin{tabular}{llllcc}
\hline $\begin{array}{l}\text { No. of } \\
\text { employees }\end{array}$ & $\begin{array}{l}\text { Compliance } \\
\text { cost (days } \\
\text { per year) }\end{array}$ & $\begin{array}{l}\text { cost of } \\
\text { compliance } \\
\text { (\$ per year) }\end{array}$ & $\begin{array}{l}\text { Implied } \\
\text { cost per } \\
\text { hour } \mathbf{( \$ )}\end{array}$ & $\begin{array}{l}\text { Total } \\
\text { sales } \\
\text { (\$) }\end{array}$ & $\begin{array}{l}\text { Cost as a } \\
\text { percent } \\
\text { of sales }\end{array}$ \\
\hline None & 5 & 3182 & 80 & 150000 & 2.1 \\
$\mathbf{1 - 5}$ & 8 & 7500 & 115 & 365000 & 2.1 \\
$\mathbf{6 - 2 0}$ & 14 & 15417 & 139 & 1523810 & 1.0 \\
\hline
\end{tabular}

Source: DARRS (2010) Survey 
Clearly compliance costs for businesses increase with firm size as does implied cost per hour. This may well reflect that the larger the firm the more complex is compliance and the need to buy in professional help. However, as the firm size increases, the relative burden of compliance, as measured by costs as a percentage of sales, falls.

\section{Figure 10: Cost of compliance by firm size}

(a) Days per year
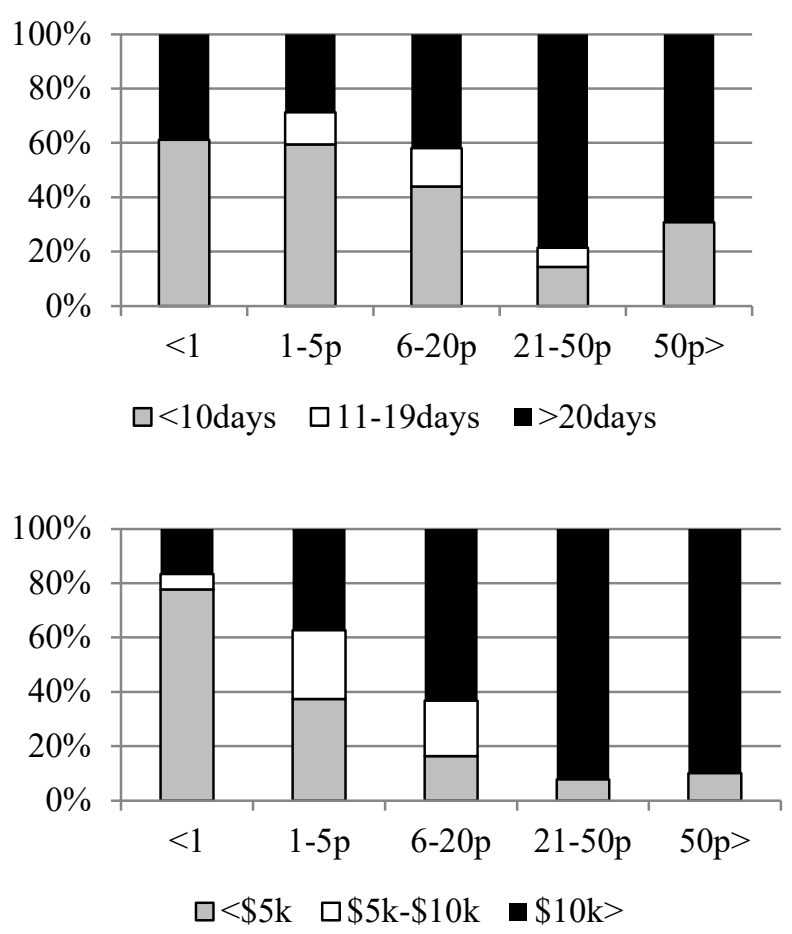

(b) Dollars

Source: DARRS (2010) Survey

Using the ABS estimates of the number of small businesses in Australia allows us to extrapolate to the economy as a whole. For small businesses, those businesses with less than 20 employees, the cost to the economy of complying with government regulations, is estimated to be over $\$ 10$ billion.

\section{Businesses' Own Views}

What do the businesses say themselves? Of the 391 firms surveyed, 226 businesses reported problems with compliance. Only seven firms reported specifically that they experienced no problems. Problems were initially categorised according to the categories suggested in the previous survey questions, namely ASIC regulation; record keeping for tax purpose; directors' duties; information disclosure; OHS; superannuation; workplace relations; maternity leave; quality assurance; and environmental protection.

In order of most problematic (defined as the percentage of all businesses who responded "difficult" or "very difficult" to each of the issues listed), the issues and percentages encountering this issue are shown in Table 2. 
Table 2: Quotations from businesses experiencing difficulties, and the percentage finding this issue difficult

\begin{tabular}{|c|c|c|}
\hline Issue & $\begin{array}{c}\text { Percentage } \\
\text { finding issue } \\
\text { difficult } \\
\end{array}$ & Quotations \\
\hline Record keeping for tax purposes & 45 & $\begin{array}{l}\text { "Taxation law and compliance - difficult to } \\
\text { follow as I am not a professor of taxation law - } \\
\text { and neither are the "helpful" folk who take calls } \\
\text { for the Tax Office (they are all subject to } \\
\text { changing their minds, that is not what I meant } \\
\text { or I will have to seek someone else's advice)" } \\
\text { "BAS - it's too complicated - not to complete, } \\
\text { but to gather and reconcile all source data. " }\end{array}$ \\
\hline $\begin{array}{l}\text { Occupational Health and Safety } \\
(\mathrm{OH} \& \mathrm{~S}) \text { - general }\end{array}$ & 40 & $\begin{array}{l}\text { "Occupational Health and Safety - very hard to } \\
\text { proactively determine level of satisfactory } \\
\text { compliance ("paper trail" measurement with } \\
\text { considerable cost/workload too often } \\
\text { applied/relied on, \& retrospectively)" } \\
\text { "OHS - Potentially serious legal consequences. } \\
\text { To get "air tight" OHS policies and procedures, } \\
\text { and train staff in these would cost tens of } \\
\text { thousands of dollars, and take a long time!" }\end{array}$ \\
\hline OH\&S - specific & & $\begin{array}{l}\text { "Occupational health \& safety regulations that } \\
\text { are not workable in small businesses in rural \& } \\
\text { regional areas." } \\
\text { "WorkCover in South Australia which requires } \\
\text { the employer to compensate for all lost wages } \\
\text { from every employment source, e.g. where } \\
\text { people have more than one job, work across } \\
\text { many businesses, and the employer has to pay } \\
\text { all lost wages for the injury. It is not worth } \\
\text { employing someone who works elsewhere." }\end{array}$ \\
\hline Workplace Relations & 32 & $\begin{array}{l}\text { "Workplace relations is out of control." } \\
\text { "Workplace Relations are more complex and } \\
\text { ever changing." } \\
\text { "Being taken to task by past staff members } \\
\text { when they were well looked after in this current } \\
\text { difficult ... market" } \\
\text { "Employees who think they are above the law" }\end{array}$ \\
\hline Superannuation & 29 & $\begin{array}{l}\text { "The mechanism is too complex and the rules / } \\
\text { penalties are draconian, especially considering } \\
\text { most of the problems / penalties happen due to } \\
\text { circumstances beyond our control." } \\
\text { "Having employees nominate super fund. It } \\
\text { creates a lot of extra time consuming } \\
\text { paperwork." } \\
\text { "Super - we are a company of } 13 \text { employees } \\
\text { with } 5 \text { different super funds - keeping all super } \\
\text { funds satisfied because of varying 'payment } \\
\text { dates' is ridiculous!" }\end{array}$ \\
\hline Quality Assurance & 26 & $\begin{array}{l}\text { "so many loopholes to fill. Seems like there is } \\
\text { always an area that needs work, and constant } \\
\text { updating" }\end{array}$ \\
\hline
\end{tabular}




\begin{tabular}{|c|c|c|}
\hline & & $\begin{array}{l}\text { "Too much useless government intervention in } \\
\text { 'quality measurement'." }\end{array}$ \\
\hline Information disclosure & 26 & $\begin{array}{l}\text { "Most significant problem is cost of technical } \\
\text { and compliance advice in relation to volume of } \\
\text { services." } \\
\text { "Compliance to company standards - costly if } \\
\text { you want to change to be fully regulated by } \\
\text { AASB" }\end{array}$ \\
\hline Environmental Protection & 24 & $\begin{array}{l}\text { "Carbon tax - this plus GST will make my } \\
\text { goods more expensive and harder to sell" } \\
\text { "Environmental compliance, but mainly in } \\
\text { respect of my clients' operations and my role as } \\
\text { a consultant providing advice to them." }\end{array}$ \\
\hline Directors duties & 20 & \\
\hline Maternity leave & 16 & $\begin{array}{l}\text { "Maternity Leave - I don't even know where to } \\
\text { start." } \\
\text { "As a sole trader, I cannot afford maternity } \\
\text { leave as it would be a double wage bill when I } \\
\text { can barely make a single wage work." } \\
\text { "Maternity leave is yet another service that } \\
\text { government is getting small business to do on } \\
\text { their behalf." }\end{array}$ \\
\hline ASIC regulation & 14 & $\begin{array}{l}\text { "Keep govt out of my business" } \\
\text { "Too many regulations across a broad spectrum } \\
\text { so that multiple advisors are required to run a } \\
\text { business" }\end{array}$ \\
\hline
\end{tabular}

Source: DARRS (2010) Survey

While none of these percentages represent a majority of firms, they are significant proportions of businesses in the sample. The top two issues for firms are "record keeping for tax purposes" and "Occupational Health and Safety".

Information disclosure was not really the term that respondents used, they complained more about compliance (which we take to be different to record keeping). Also it would be interesting to know what respondents thought of when they saw the term "information disclosure." We assume they are treating it as information that has to be sent on to the ATO, ASIC or a similar government regulator, and record keeping is a more internal mechanism that could even be a precursor to information disclosure. We do not think that businesses are thinking here of disclosure such as reporting oil spillages.

Directors' duties did not attract any problems in the free text. The survey data shows that only 34 percent of non-missing respondents had a board of directors and the size of most responding firms (less than 20 employees) suggests that directors' duties are unlikely to be a major source of difficulty. This is despite the fact that Adams (2011) reports on the comparative ineffectiveness of the "business judgment rule" when ASIC pursues litigation. 
Table 3: Other themes

\begin{tabular}{|l|l|}
\hline Category & Quotation \\
\hline Tax in general & "The complexity of tax law" \\
"Excessive and complex taxation" \\
"Difficulty in meeting BAS funding and deadlines"
\end{tabular}

Source: DARRS (2010) Survey

Other themes expressed by businesses in the free text comments that were not specifically mentioned in the categories of difficulty are listed below. The record keeping item in the survey was too specific, so we captured a whole variety of tax-related problems such as the following. Chittenden et al. (2003) reporting on the Working Overtime Survey of 1996 also noted complexity of taxation and employment regulations.

\section{What Does Business Suggest?}

179 businesses suggested solutions. Six stated that they could not think of any solutions required. From the solutions, we constructed our own categories based on the responses received. These categories are shown in Table 4, along with some representative quotes from businesses. 
Table 4: Suggested Solutions.

\begin{tabular}{|c|c|}
\hline Category & Quotation \\
\hline Light-hearted & $\begin{array}{l}\text { "Don't be a small business!!!" } \\
\text { "Provide larger heads for the small operator of small } \\
\text { business and not expect them to be more knowledgeable } \\
\text { than the Commissioner for Taxation, the Director of } \\
\text { Workplace relations, etc. all at the same time." }\end{array}$ \\
\hline $\begin{array}{l}\text { Simplification including common } \\
\text { sense }\end{array}$ & $\begin{array}{l}\text { "Fewer rules! Fewer laws!" } \\
\text { "Simplify the legislation" } \\
\text { "Simplify!!!" } \\
\text { "Don't keep making laws that punish most businesses } \\
\text { just to deter the one or two bad eggs in an industry - } \\
\text { they will do it any way." } \\
\text { "There should be levels of compliance depending on the } \\
\text { size of the organization without putting larger } \\
\text { organisations at a disadvantage, and without putting } \\
\text { employees at risk. These levels should be based on } \\
\text { total number of employees" } \\
\text { "Common sense to be brought back in as to what is } \\
\text { really necessary or bring in fierce penalties to all } \\
\text { businesses that don't met all regulations. The well ran } \\
\text { shops are disadvantaged by having a much higher } \\
\text { hourly rate than those shops that don't conform" }\end{array}$ \\
\hline Online solutions & $\begin{array}{l}\text { "Not so much remedies but provide free user friendly } \\
\text { online options of compliance tools- that take you } \\
\text { through wizards and print out a "what you should be } \\
\text { doing- what you could be doing" reports" } \\
\text { "Allow the use of online registrations and paying of } \\
\text { annual fees and changing information. Make it easier to } \\
\text { use and not so much done time and timing out." }\end{array}$ \\
\hline Assistance & $\begin{array}{l}\text { "Further training offered at the expense of the } \\
\text { regulators e.g. WorkCover, ATO" } \\
\text { "more assistance less of a willingness to fine and } \\
\text { punish" }\end{array}$ \\
\hline Communication & $\begin{array}{l}\text { "regular broadcasting in plain straight forward English" } \\
\text { "consult more widely with business and industry groups }\end{array}$ \\
\hline
\end{tabular}




\begin{tabular}{|c|c|}
\hline & $\begin{array}{l}\text { and have legislation and regulation written in plain } \\
\text { English that the average small business operator can } \\
\text { comprehend" }\end{array}$ \\
\hline Payments to businesses & $\begin{array}{l}\text { "being paid to be a tax collector - GST, employee } \\
\text { PAYG - the ATO expects us to work for them for free" } \\
\text { "Govt to reimburse small business for the time spent on } \\
\text { compliance at say } \$ 100 \text { per hour. This would stimulate } \\
\text { an interest by government to reduce time of compliance } \\
\text { and would make small business more interested in } \\
\text { complying" }\end{array}$ \\
\hline Specific workplace relations solutions & $\begin{array}{l}\text { "Being able to sack an employee for being lazy and } \\
\text { incompetent" } \\
\text { "A Fair Work Australia for employers be set up." }\end{array}$ \\
\hline Specific OHS solutions & $\begin{array}{l}\text { "Let the workers develop their own OH \& S policies } \\
\text { and procedures in agreement with the executives not the } \\
\text { other way around" } \\
\text { "reverse onus of proof for workers compensation i.e. } \\
\text { workers have to prove that they have actually been } \\
\text { injured and if injured that their injuries occurred at } \\
\text { work" }\end{array}$ \\
\hline $\begin{array}{l}\text { Specific tax changes (generally } \\
\text { reductions or exemptions) }\end{array}$ & $\begin{array}{l}\text { "Flat tax" } \\
\text { "Increase GST to } 15 \text { percent and drop all other taxes" } \\
\text { "GST free for business under } \$ 250,000 "\end{array}$ \\
\hline Consistency & $\begin{array}{l}\text { "Have one taxing body for the whole of the country and } \\
\text { take away state taxes that are a disincentive for growth } \\
\text { and investment." } \\
\text { "Simple consistent federal rules to replace the eight } \\
\text { state systems" }\end{array}$ \\
\hline Federal government responses & $\begin{array}{l}\text { "call a new election" } \\
\text { "bring in working for payments, compulsory military } \\
\text { for youth unemployed, make everyone work to ease the } \\
\text { burden off small business and govt can get taxes from } \\
\text { everyone not just working - middle class. Change in } \\
\text { govt would also help small business" }\end{array}$ \\
\hline
\end{tabular}

Source: DARRS (2010) Survey 


\section{Summary and Discussion}

In summary there is a significant frustration among many businesses regarding government regulation. One consistent theme is responsibility. In general Government attempts to move the responsibility for items ranging from using the nominated super fund of every employee to funding maternity leave to collecting taxes from Government to business.

A second consistent theme is change. This can refer to change in a given regulation over time, or changes that arise from inconsistencies between states. Small businesses may not have the capacity to keep up with all the changes and inconsistencies. They may not recognise that such change has occurred. Whether or not they are complying with the latest version of regulation, businesses must comply and then be able to prove that they have complied.

From the written responses, generally speaking, the main concern are of the amount of paperwork involved in keeping compliant and the complexity of the regulations exacerbated by various states and jurisdictions with different rules. These factors, in turn, create other problems, frequently reported in the written section, such as the difficulty keeping compliant with government regulation including getting staff to comply with government regulation, maintaining deadlines and understanding the requirements of government regulation. This is not helped by poor quality or overabundance of information which needs to be sifted through to find relevant information; also frequently commented on. These factors lead to a common charge from business that government over regulates the business sector making compliance costs greater than they need be. Furthermore, there is a common theme regarding additional regulation needed to fulfil the function of government, such as collecting taxes and superannuation payments, without any remuneration for the additional drain on the firm's resources to provide such functions.

The attitudes of business regarding taxation compliance mostly focused on the amount of paperwork necessary and the difficulties associated in keeping compliant. The issue of paperwork had the greatest representation in taxation compliance. These factors appear to be the main factors explaining why businesses frequently suggested taxation compliance is costly and time consuming.

Interestingly industrial relations had the greatest frequency of businesses from the survey complaining about the costly nature of the regulation. Businesses in the survey suggested that there was significant inequality arising from the regulation in its current form. There is a perceived inequality in the form of greater rights for the employees over the employers. Furthermore, industrial relations is regarded as considerably over regulated.

Of the areas of regulation, occupational health and safety had by far the greatest frequency of businesses complaining about the difficulty they experience in keeping compliant. Especially in ensuring employees remain compliant with government regulation. This and the associated paperwork necessary to maintain compliant causing occupational health and safety were thought to be very costly.

The last area of government regulation frequently complained about in the survey, superannuation, picks up on an interesting and more common complaint from businesses regarding government regulation. Businesses feel they should be compensated for filling a role that is primarily the function of government. That is, businesses are responsible for collecting and making superannuation payments on behalf of employees. The complexity of this task made considerably harder by the fact that employees nominate their own superannuation fund.

Chittenden et al. (2003) note that the Better Regulation Task Force (BRTF) as having "simplified procedures for SMEs" as their final suggestion for reducing regulatory burden. When Chittenden et al. (2003) were writing, the full potential of the internet had not been realised (and probably still has not been!). They note that the BRTF suggested compliance mechanisms such as automated payroll services might help reduce the regulatory burden. Heenetigala and Armstrong (2010) have studied how accountants could assist small businesses to make better use of online solutions for communication with themselves. According to their findings, ICT would be beneficial to either small business, accountants, or both. Dai (2010) has also explored the potential of specific software to link small businesses with ICT solutions and increase productivity. Compensation (in the context of 
administrative responsibilities being moved from the public to the private sector) or incentives (in the context of electronic filing of tax returns) as suggested by the BRTF (Chittenden et al. 2003) could also be a solution.

Banks (2006) mentions "risk aversion" as an increasing community attitude that may be leading to over-zealous regulation. Vickers et al. (2005) studied small business response to Occupational Health and Safety regulation in the UK. The solutions they were proposing were not directly drawn from respondents but grew from their analysis of the data: the most radical one was a proposal to increase inspections.

Our findings are in agreement with the view that a lack of coordination between government agencies as a frustration for a majority of small firms. This is likely to refer to federal agencies. Banks (2006) has also suggested consistency and harmonisation as key reforms worthy of attention. Clarke (2010) proposes some federal solutions, in particular the concept of a network of organisations that work together to ensure compliance. Such a network could include peak bodies such as COSBOA or other industry associations.

Our research has provided estimates of the compliance costs of regulation to small business which, although they may not be exact, do suggest these costs are significant and result in inefficiency for business and the economy. For small businesses the cost to the economy of complying with government regulations, is estimated to be over $\$ 10$ billion. The research has also identified key areas of concern for small business and some solutions to ameliorating the burden of regulation. In many ways the findings leave considerable scope for further research. It does, nevertheless, fill a gap in the Australian literature in this area.

\section{References}

Adams, M. (2011), Latest developments in officers' duties of SMEs. Journal of Business Systems, Governance and Ethics 6(3), $31-42$.

Australian Bureau of Statistics (2007), Counts of Australian Business Operators, Cat No. 8175.0.

Australian Bureau of Statistics (2012), Australian Industry, Cat No 8155.0.

Australian Chamber of Commerce and Industry (2005) ACCI Submission to the Office of the Federal Privacy Commission, December, Canberra.

Banks, G. (2006), Rethinking Regulation, Report of the Taskforce on Reducing Regulatory Burdens on Business, available at www.regulationtaskforce.gov.au.

Bell, C. (1996), Time for Business, Report to the Small Business Deregulation Task Force, Productivity Commission, Canberra.

Chittenden, F., Kauser, S. and Poutziouris, P. (2002), Regulatory Burden of Small Business: A Literature Review, the University of Manchester, Manchester, UK.

Chittenden, F., Kauser, S. and Poutziouris, P. (2003), Tax regulation and small business in the UK, Australia and New Zealand, International Small Business Journal 21, 93 - 115.

Clarke, A. (2010), Small corporations: better controlling of the spigot of "red tape", Journal of Business Systems, Governance and Ethics 4(4), $61-69$.

Dai, W. (2010), The impact of emerging technologies on small and medium enterprises (SMEs), Journal of Business Systems, Governance and Ethics 4(4), 53 - 60.

Heenetigala, K. and Armstrong, A. (2010). The use of internet reporting for small business, Journal of Business Systems, Governance and Ethics 4(4), $41-52$.

Heenetigala, K., Armstrong, A. and Clarke, A. (2011), Corporate regulation and corporate governance of small businesses in Australia, Journal of Business Systems, Governance and Ethics 6(3), 43 52.

Inland Revenue (1998), The Tax Compliance Costs for Employers of PAYE and National Insurance in 1995-96, The Centre for Fiscal Studies, University of Bath, Bath.

Li, Y., Armstrong, A. and Clarke, A. (2012). Determinants of regulatory burdens on non-listed small corporations in Australia: perceptions of small corporations' owner/managers. Journal of Business Systems, Governance and Ethics 7(1), $39-51$. 
Pope, J., (1992) The Compliance Costs of Taxation in Australia: An Economic and Policy Perspective, Working Paper no 92.07, School of Economics and Finance, Curtin University of Technology, Perth.

Pope, J., Fayle R. and Chen D.L. (1991), 'The Compliance Costs of Public Companies' Income Taxation in Australia 1986/87', Australia Tax Research Foundation, Sydney.

Pope, J. Fayle R. and Chen D.L. (1989), The Compliance Costs of Personal Income Tax in Australia, Australian Tax Research Foundation

Pope, J. Fayle R. and Chen D.L.(1992), The Compliance Costs of Employment Related Taxation in Australia, Australian Tax Research Foundation.

Pope, J., Fayle R. and Duncanson M. (1990), The Compliance Costs of Personal Income Taxation in Australia, 1986/87, Australian Tax Research Foundation, Sydney.

Productivity Commission (2007) Performance Benchmarking of Australian Business Regulation, Productivity Commission, Canberra.

Vickers, I., James, P., Smallbone, D. and Baldock, R. (2005). Understanding small firm responses to regulation, Policy Studies 26(2), 149-169.

Sandford, C. And Hasseldine, J. (1992) The Compliance Costs of Business Taxes in New Zealand, Institute of Policy Studies, Victoria University of Wellington, Wellington.

Sandford, C., Godwin, M., and Hardwick, P. (1989) Administrative and Compliance Costs of Taxation, Fiscal Publications, Bath.

Small Business Deregulation Task Force (1996), Working Overtime: A National Survey of the Paperwork Burden on Small Business, Background Paper 3, October, Small Business Deregulation Task Force, Canberra. 
